\title{
SKAUSMAS SPORTE: SKAUSMO SUVOKIMO IR JO IVEIKOS STRATEGIJŲ RYŠYS
}

\author{
Lina Vaisetaité ${ }^{1}$, Rūta Sargautyte் $\dot{e}^{2}$ \\ Vilniaus olimpinis sporto centras ${ }^{1}$, Vilniaus universitetas ${ }^{2}$, Vilnius, Lietuva
}

\begin{abstract}
Lina Vaisetaitè. Psichologijos magistrè. Vilniaus olimpinio sporto centro psichologè. Mokslinių tyrimų kryptis — psichologiniai igūdžiai sporte, skausmo suvokimas ir iveika sporte.

Rūta Sargautytė. Socialinių mokslų daktarè. Vilniaus universiteto Klinikinès ir organizacinès psichologijos katedros docentė. Mokslinių tyrimų kryptis — psichologija medicinoje, skausmo psichologija, pacientų mokymas.
\end{abstract}

\section{SANTRAUKA}

Tyrimo tikslas - išsiaiškinti, kaip sportininkai suvokia skausma bei kokie skausmo suvokimo ir skausmo ìveikos strategiju naudojimo dažnumo ryšiai. Straipsnyje nagrinejamas raumenu, gyjančios traumos ir ìsisenejusio skausmo suvokimas bei iveika.

Buvo apklausta 50 sportininku (lengvaatlečiu, irkluotoju, dviratininku ir plaukiku). Jie pilde anketas, sudarytas pagal vizualaus atitikmens skales (Huskisson, 1974), semantinio diferencialo metodikos (Suslavičius, 1988) ir PMS-I (Kleinert, 2002) klausimyna.

Rezultatai parodè, kad raumenu skausmo intensyvumas vertinamas vidutiniškai 42,64 balo, gyjančios traumos - 60,51 balo, o ìsisenejjęs - 57,81 balo. Raumenu skausmas juvertintas kaip silpnesnis nei gyjančios traumos ar isisenėjęs (abiem atvejais $p<0,01$ ). Pagal semantinio diferencialo skales skausmas nepriklausomai nuo jo tipo suvokiamas kaip blogas, bjaurus, stiprus, sunkus, ümus, ìtempiantis, silpnejjantis ir varginantis. Raumenu skausmas suvokiamas kaip naudingas, o gyjančios traumos ir ỉsisenejęs — kaip žalingas. Taip pat buvo nustatyti skausmo intensyvumo ¿̇verčiu, skausmo suvokimo pagal semantinio diferencialo skales ir skausmo ¿̇veikos strategiju naudojimo dažnumo ryšiai, ir jie priklausè nuo skausmo tipo bei įveikos strategiju.

Raktažodžiai: skausmo suvokimas, skausmo įveikos strategijos, raumenu skausmas, traumos skausmas, įsisenejjęs skausmas.

\section{IVADAS}

$\mathrm{S}$ portuojant dažnai tenka patirti fizinị skausmą. Siekdami, kad skausmas būtų lengviau ištveriamas, kad mažiau trukdytų treniruotis ar varžytis, sportininkai naudoja ịvairias įveikos strategijas. Iveika yra suprantama kaip sąmoningos pastangos pakeisti stresinę situaciją (šiuo atveju skausmo potyri) arba praplèsti susitvarkymo su ja galimybes (Anshel, 2001). Konkretūs veiksmai, pavyzdžiui, savęs padrąsinimas, informacijos ieškojimas, relaksacija ir kt. (Kleinert, 2002), leidžiantys sumažinti patiriamą skausmą arba keičiantys jo keliamas emocijas ar mintis, vadinami skausmo i̇veikos strategijomis.

Iveikos strategiju pasirinkimas pirmiausia siejamas su kognityviuoju skausmo ivertinimu, t. y. skausmo pojūtis vertinamas kaip iššūkis, kaip grèsmė ar žala (Addison et al., 1998). Kognityvusis skausmo ívertinimas rodo labai apibendrintą skausmo suvokimą. Literatūroje nurodoma, kad ivveikos strategijų naudojimo dažnumas yra susijęs 
su konkretesniais skausmo suvokimo aspektais, pavyzdžiui, su suvoktu skausmo intensyvumu (Azevedo, Samulski, 2003). Dauguma tyrimu, skirtų šiems ryšiams nustatyti, parodè, kad skausmo intensyvumas yra susijęs tik su kai kuriu strategijų naudojimo dažnumu, pavyzdžiui, dramatizavimu (Lefevbre et al., 1995), malda ir tikejjimu (McCracken et al., 1998), pasidavimu (Azevedo, Samulski, 2003). Be to, dauguma minètų tyrimų atlikta ne su sportininkais, o su lètinio skausmo pacientais. Taigi sportineje veikloje patiriamo skausmo intensyvumo ryšiai su jo įveikos strategijų dažnumu lieka nepakankamai ištyrinèta sritis.

Kitas skausmo suvokimo aspektas - skausmo konotacinè reikšmè, nurodanti sportininko santyki su skausmu (Suslavičius, 1988). Nors tai svarbi tyrimo sritis, tokio pobūdžio tyrimų mums nepavyko rasti. Manome, kad konotacinè skausmo reikšmė, viena vertus, turètų būti susijusi su kognityviuoju skausmo įvertinimu, nes rodo patiriamo skausmo interpretacijas ivairiais aspektais. Kita vertus, ji rodo skausmo suvokimą konkrečiose skalèse, todèl informacija apie skausmo suvokimo ir jo iveikos strategijų naudojimo dažnumo ryšius gali suteikti daugiau nei kognityvusis skausmo įvertinimas. Nors kitų autorių darbų, kuriuose būtų tirtas sportininkų skausmo suvokimas pagal semantinio diferencialo metodika, rasti nepavyko, iš dalies galima remtis V. Scott ir K. Gijsbers (1981) tyrimu. Jis pateike tokius plaukikų skausmo įvertinimus: tvinkčiojantis, spaudžiantis, spazmuojantis, geliantis, sunkus, varginantis, sekinantis, stiprus. Deja, šiu autorių tyrimas neparodo minètų skausmo įvertinimų ryšio su suvoktu skausmo intensyvumu.

Kadangi kitų autorių tyrimai (Kleinert, 2002) parodè, kad skausmo įveikos strategijų naudojimo dažnumas skiriasi priklausomai nuo skausmo tipo, savo tyrimo objektu pasirinkome atskirai nagrinèti tris skausmo tipus - raumenų, gyjančios traumos ir įsisenejusi skausmą. Jie panašūs tuo, kad trunka sąlygiškai ilgą laiką, yra pasikartojantys, tačiau juos sukelia skirtingos priežastys.

Taigi tyrimo metu kèlème tokius tikslus:

1. Išsiaiškinti, kaip sportininkai suvokia raumenų, gyjančios traumos ir įsisenèjusį skausmą.

2. Nustatyti, ar yra ryšys tarp:

a) skausmo intensyvumo suvokimo ir iqveikos strategijų naudojimo dažnumo;

b) skausmo suvokimo pagal semantinio diferencialo metodiką ir įveikos strategiju naudojimo dažnumo.

\section{TYRIMO METODAI}

Tyrimo metu apklausėme 50 sportininku -17 moterų ir 33 vyrus (amžiaus vidurkis - 17,64 metu). Apklaustieji kultivavo šias sporto šakas: lengvają atletika, t. y. bėgimą $(\mathrm{n}=18)$, irklavimą $(n=15)$, dviračių sportą $(n=6)$ ir plaukimą $(\mathrm{n}=11)$.

Tyrimo metu sportininkams buvo pateikta anketa, kurią sudare kelios dalys, skirtos demografinei informacijai apie dalyvius surinkti, skausmo suvokimui bei îveikos strategijų naudojimo dažnumui ịvertinti. Visos skalès pildomos tris kartus (atskirai vertinamas raumenu, gyjančios traumos ir įsisenejjęs skausmas). Sportininkai buvo prašomi prisiminti atitinkamo skausmo potyrị ir atsakyti i pateiktus klausimus.

Skausmo intensyvumą tiriamieji vertino vizualaus atitikmens skale (VAS, Huskisson, 1974) nuo „nèra skausmo“ ( 0 balų) iki „nepakeliamas skausmas" (100 balu). Skausmo konotacinè reikšmė buvo vertinama semantinio diferencialo metodika (Suslavičius, 1988), kurią sudarè 9 skalès su būdvardžiais: blogas / geras, žalingas / naudingas, bjaurus / malonus, silpnas / stiprus, lengvas / sunkus, nenusakomas / ümus, atpalaiduojantis / itempiantis, silpnejantis / stiprejjantis, raminantis / varginantis (čia 3 reiškè labai artimą sąsają su kairèje nurodytu būdvardžiu, o +3 - labai artimą sąsają su dešinèje nurodytu).

Apklaustieji sportininkai turejo užpildyti PMSI klausimyną (Kleinert, 2002) ir nurodyti, kaip dažnai naudoja 8 skausmo įveikos strategijas: pasidavimą (strategijas, rodančias negebèjimą valdyti skausmo, skausmo neigimą arba pasidavimą jam netikint, kad galima kažką pakeisti); teigiamas saviinstrukcijas (pozityvią vidinę kalbą, savęs padrąsinimą); relaksaciją (mėginimus įveikti skausmą atpalaiduojant kūno įtampą, keičiant kūno pozą); informacijos paiešką (skausmo pojūčio analizavimą); judejjimą (skausmo mažinimą judejjimu); planavimą (strategijas, rodančias mėginimus ịveikti skausmą, užsibrěžiant konkrečius tikslus); palyginimą (esamos situacijos lyginamą su kitomis); dèmesio atitraukimą (užsiëmimą veikla, nesusijusia su sportu). Naudojamų strategijų dažnumas buvo vertinamas 5 balų skale nuo 0 (niekada) iki 5 (visada).

\section{REZULTATAI}

Tyrimo metu apklausti sportininkai raumenu skausmo intensyvumą vidutiniškai įvertino 
42,64 balo, gyjančios traumos - 60,51 balo, o ísisenejjusi - 57,81 balo. Raumenu skausmo intensyvumo įvertis statistiškai reikšmingai skyrèsi nuo gyjančios traumos $(p=0,009)$ ir ísisenejjusio skausmo intensyvumo íverčio $(p=0,005)$.

Rezultatai, gauti apskaičiavus kiekvienos semantinio diferencialo skalès vidurki, rodo, kad raumenu skausmas suvokiamas kaip blogas $(\mathrm{M}=-0,43)$, naudingas $(\mathrm{M}=0,56)$, bjaurus $(\mathrm{M}=-0,78)$, stiprus $(M=0,64)$, sunkus $(M=0,51)$, ūmus $(M=0,45)$, itempiantis $(M=0,96)$, silpnejantis $(M=-0,18)$, varginantis $(M=1,42)$. Gyjančios traumos skausmas suvokiamas kaip blogas $(\mathrm{M}=-1,18)$, žalingas $(\mathrm{M}=-1,13)$, bjaurus $(\mathrm{M}=-1,54)$, stiprus $(M=0,87)$, sunkus $(M=0,90)$, ūmus $(M=0,56)$, itempiantis $(M=1,36)$, silpnejantis $(M=-1,03)$, varginantis $(M=1,54)$. Isisenèjęs skausmas suvokiamas kaip blogas $(\mathrm{M}=-1,45)$, žalingas $(\mathrm{M}=-1,35)$, bjaurus $(\mathrm{M}=-1,61)$, stiprus $(\mathrm{M}=0,47)$, sunkus $(\mathrm{M}=0,84)$, ūmus $(\mathrm{M}=0,34)$, itempiantis $(M=1,59)$, silpnejantis $(M=-0,054)$, varginantis $(M=1,53)$. Kaip parodė Wilcoxon porinių imčių neparametrinis kriterijus, raumenų ir gyjančios traumos skausmo suvokimas statistiškai reikšmingai skyrèsi dviejose skalèse. Nors skaleje bjaurus / malonus abu skausmo tipai suvokiami kaip artimiau susiję su būdvardžiu bjaurus, raumenu skausmo ivverčio reikšmè statistiškai reikšmingai mažesnè $(p=0,027)$. Dar aiškesnis skirtumas skalėje žalingas / naudingas, kur raumenų skausmas suvokiamas kaip naudingas, o gyjančios traumos - kaip žalingas $(p=0,0001)$. Palyginus su isisenejjusio skausmo suvokimu, raumenų skausmas suvokiamas kaip ne toks bjau- rus $(p=0,015)$, ne toks blogas $(p=0,012)$, ne toks itempiantis $(p=0,002)$ ir ne toks sunkus $(\mathrm{p}=0,045)$, taip pat naudingas, kai tuo tarpu isisenėjęs skausmas suvokiamas kaip žalingas $(\mathrm{p}=0,0001)$ (žr. 1 pav.).

Skausmo suvokimo ir įveikos strategijų naudojimo dažnumo ryšys. Raumenų skausmo intensyvumo ivertinimas, kaip parode Pirsono koreliacijos koeficientas, statistiškai reikšmingai susijęs tik su planavimo strategijos dažnumu $(r=0,383 ; p=0,008)$. Gyjančios traumos skausmo intensyvumo įvertinimas statistiškai reikšmingai susijęs su relaksacijos $(r=0,367 ; p=0,03)$ ir dèmesio atitraukimo $(r=0,352 ; p=0,038)$ strategijų dažnumu. Isisenejjusio skausmo intensyvumo ¿̇vertinimas susijęs su relaksacijos $(r=0,496$; $\mathrm{p}=0,008)$ ir informacijos paieškos $(\mathrm{r}=0,485$; $\mathrm{p}=0,01)$ įveikos strategijomis (žr. 1 lent.).

Raumenu skausmo suvokimas: skaléje bjaurus / malonus susijęs su relaksacija $(\mathrm{r}=-0,353 ; \mathrm{p}=0,017)$, planavimu $(\mathrm{r}=-0,384$; $\mathrm{p}=0,009)$ ir dèmesio atitraukimu $(\mathrm{r}=-0,308$; $\mathrm{p}=0,04)$; skalèje geras / blogas - su relaksacija $(r=-0,345 ; p=0,022)$ ir dèmesio atitraukimu $(\mathrm{r}=-0,314 ; \mathrm{p}=0,038)$; skalèje raminantis / varginantis - su palyginimu $(\mathrm{r}=-0,380 ; \mathrm{p}=0,01)$. Gyjančios traumos skausmo suvokimas: skaleje geras / blogas susijęs su demesio atitraukimu $(\mathrm{r}=-0,454 ; \mathrm{p}=0,007)$; skaleje žalingas / naudingas - su pasidavimu $(\mathrm{r}=-0,452 ; \mathrm{p}=0,007)$, teigiamomis saviinstrukcijomis $(\mathrm{r}=0,345 ; \mathrm{p}=0,046)$ ir demesio atitraukimu $(\mathrm{r}=-0,345 ; 0,046)$; skaleje raminantis / varginantis - su planavimu $(\mathrm{r}=0,376 ; \mathrm{p}=0,028)$; ska-

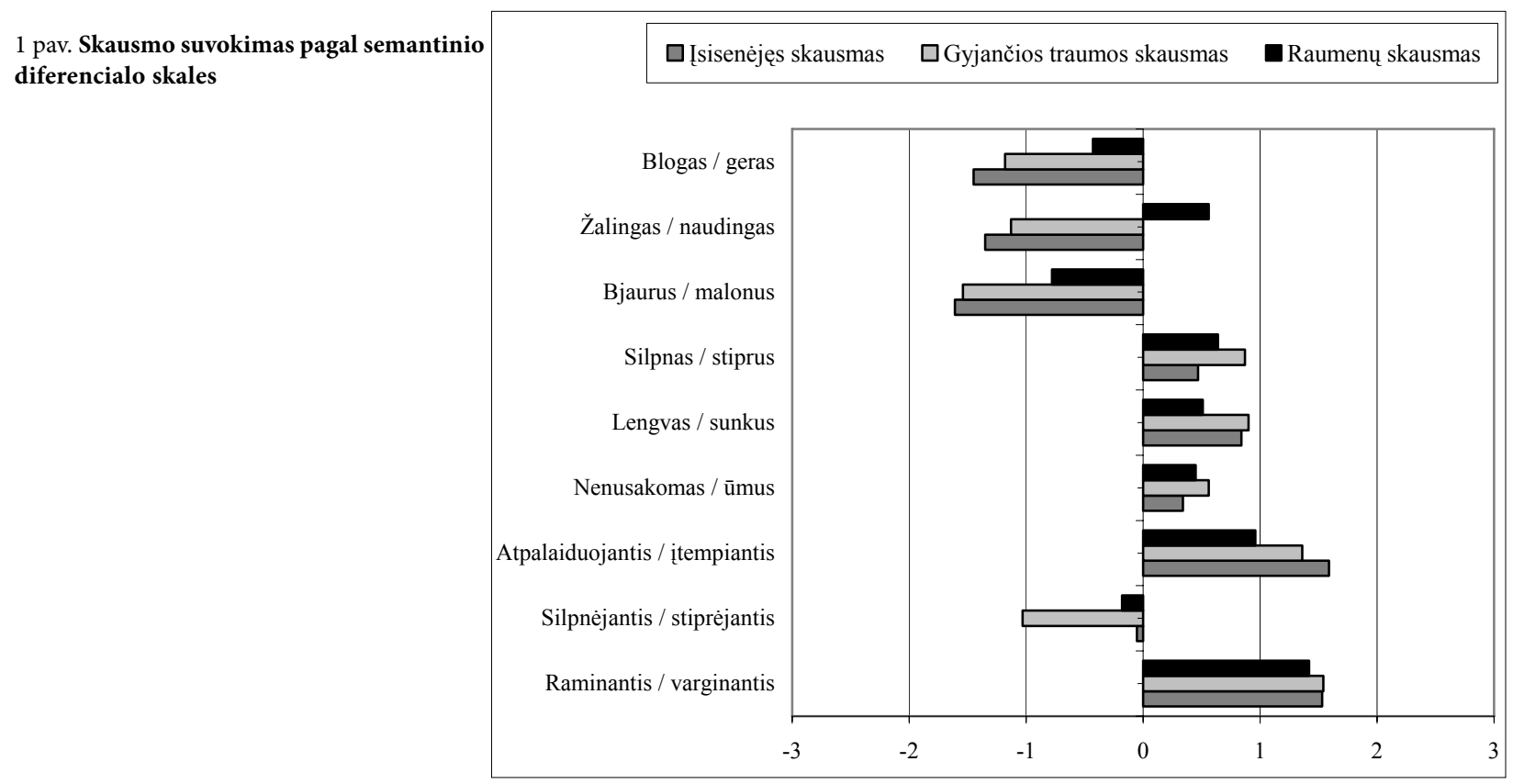


Lentelè. Skausmo intensyvumo ir to paties tipo skausmo ịveikos strategijų ryšys

Pastaba. ${ }^{* *}-$ koreliacija statistiškai reikšminga, $\mathrm{p}<0,01$; $^{\star}$ - koreliacija statistiškai reikšminga, $\mathrm{p}<0,05 ; \mathrm{r}-$ Pirsono koreliacijos koeficientas.

2 pav. Skausmo suvokimo ir skausmo įveikos strategijų ryšiai

\begin{tabular}{|l|c|c|c|c|c|c|}
\hline \multirow{2}{*}{ Iveikos strategijos } & \multicolumn{2}{|c|}{ Raumenu } & \multicolumn{2}{c|}{ Gyjančios traumos } & \multicolumn{3}{c|}{ Isisenèjęs } \\
\hline Pasidavimas & $\mathrm{r}$ & $-0,160$ & $\mathrm{r}$ & 0,030 & $\mathrm{r}$ & $-0,205$ \\
\hline Teigiamos saviinstrukcijos & $\mathrm{r}$ & 0,123 & $\mathrm{r}$ & 0,138 & $\mathrm{r}$ & 0,093 \\
\hline Relaksacija & $\mathrm{r}$ & 0,075 & $\mathrm{r}$ & $\mathbf{0 , 3 6 7 *}$ & $\mathrm{r}$ & $\mathbf{0 , 4 9 6 * *}$ \\
\hline Informacijos paieška & $\mathrm{r}$ & 0,053 & $\mathrm{r}$ & 0,126 & $\mathrm{r}$ & $\mathbf{0 , 4 8 5 *}$ \\
\hline Judejjimas & $\mathrm{r}$ & $-0,160$ & $\mathrm{r}$ & $-0,093$ & $\mathrm{r}$ & 0,245 \\
\hline Planavimas & $\mathrm{r}$ & $\mathbf{0 , 3 8 3 * *}$ & $\mathrm{r}$ & 0,297 & $\mathrm{r}$ & 0,319 \\
\hline Palyginimas & $\mathrm{r}$ & 0,104 & $\mathrm{r}$ & $-0,143$ & $\mathrm{r}$ & $-0,185$ \\
\hline Dėmesio atitraukimas & $\mathrm{r}$ & 0,149 & $\mathrm{r}$ & $\mathbf{0 , 3 5 2 *}$ & $\mathrm{r}$ & $-0,162$ \\
\hline
\end{tabular}

Pastaba. Ryšiai: $\boldsymbol{\nabla}$ - raumenu skausmo; gyjančios traumos skausmo; , $\boldsymbol{\nabla}$ - isisenejusio skausmo.

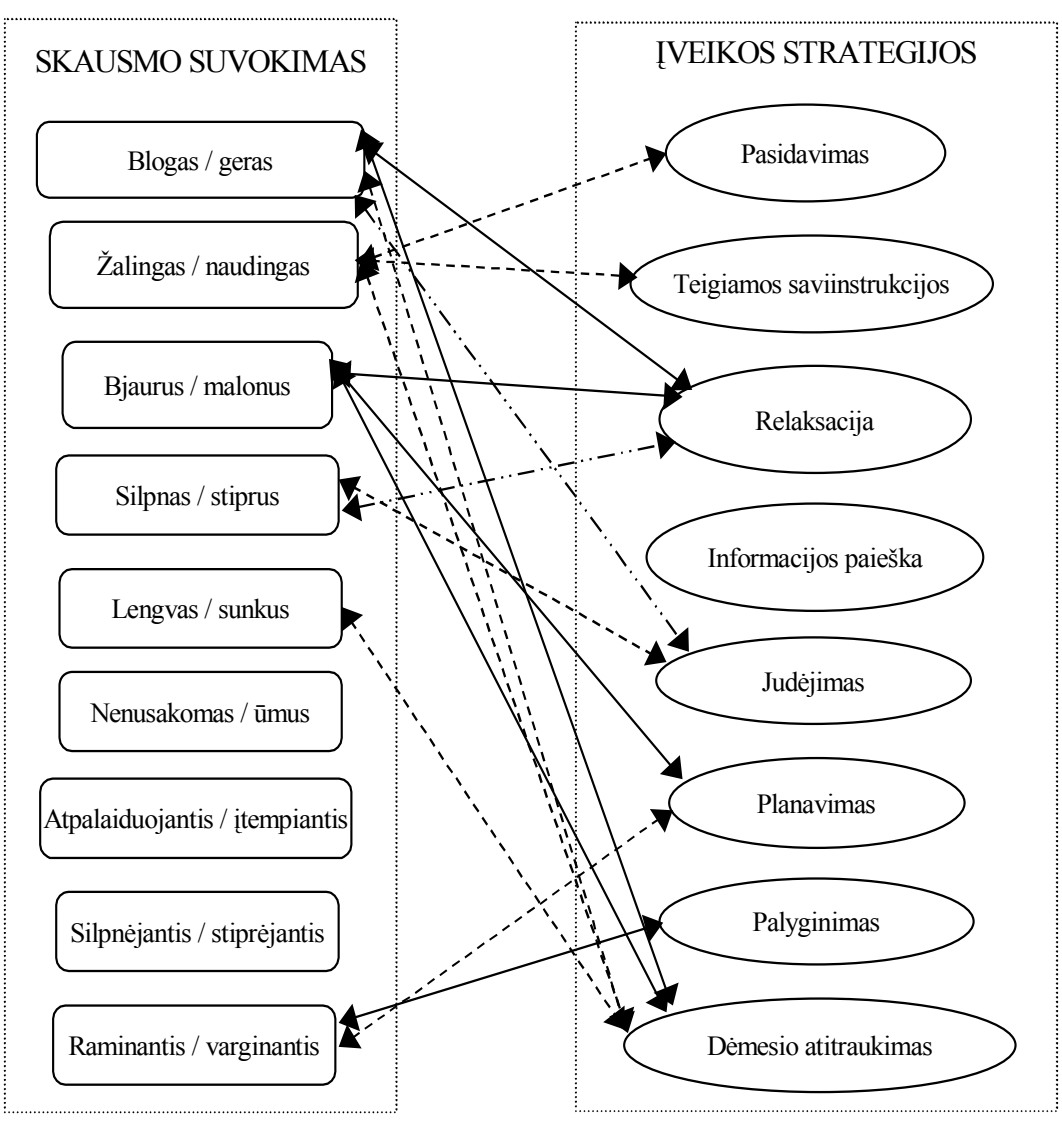

lèje silpnas / stiprus — su judejimu ( $\mathrm{r}=-0,364$; $\mathrm{p}=0,034)$; skaleje lengvas / sunkus — su dèmesio atitraukimu $(r=0,360 ; p=0,037)$. Isisenejjusio skausmo suvokimas: skaleje geras / blogas susijęs su judejimo strategija $(\mathrm{r}=0,406 ; \mathrm{p}=0,044)$; skalèje silpnas / stiprus — su relaksacija $(\mathrm{r}=0,486$; $\mathrm{p}=0,014)$ (žr. 2 pav.).

\section{REZULTATUQ APTARIMAS}

Tyrimo rezultatai rodo, kad nepriklausomai nuo skausmo tipo šiam potyriui yra priskiriamos gana neigiamos reikšmès - skausmas suvokiamas kaip blogas, bjaurus, stiprus, sunkus, ūmus, itempiantis, silpnejantis ir varginantis. Tokie tyrimo rezultatai sutampa su kitų autorių gautaisiais. Pavyzdžiui, V. Scott ir K. Gijsbers (1981) tirti sportininkai skausmą ịvardijo kaip varginantị ir sunkų, T. Addison ir kt. (1998) tiriamujų skausmo potyris buvo apibūdintas kaip nemalonus.

Atlikto tyrimo rezultatai rodo, kad skausmas kontinuume žalingas / naudingas ne visuomet suvokiamas kaip žalingas. Tai patvirtina ir kitu autoriu (Roessler, 2003; Addison et al., 1998; Scott, Gijsbers, 1981) išvadas, kad skausmas sporte - ne tik grèsmès ar žalos ženklas, bet rodo ir savo galimybių ribos peržengimą, adekvačias pastangas ir treniruočiu krūvị.

Tyrimo rezultatai, kaip ir buvo tikètasi, patvirtino, kad skausmo įveikos strategijų naudojimo dažnumas yra susijęs su skausmo suvokimu. Tiesa, šie ryšiai priklauso nuo skausmo tipo. Sportininkai yra linkę dažniau naudoti planavimo strategija raumenų skausmo įveikai, relaksaciją — gyjančios 
traumos bei įsisenėjusiam skausmui įveikti, o informacijos paieškos strategiją — isisenejusiam skausmui iveikti tuomet, kai skausmas suvokiamas kaip intensyvesnis, todèl gali būti, kad šios strategijos yra paveikesnès esant intensyvesniam skausmui. Kita vertus, dažnesnis tokios strategijos kaip demesio atitraukimas naudojimas tuomet, kai patiriamas gyjančios traumos skausmas, gali tik sustiprinti skausmo intensyvumo suvokimą, nes mažina skausmo kontrolès jausmą (Haythornwaite et. al., 1998). Kitaip tariant, rastų ryšiu kryptis nèra visiškai aiški. Vienais atvejais tam tikros ivveikos strategijos yra paveikesnès esant tam tikro intensyvumo skausmui, kitais - iveikos strategiju naudojimas gali keisti pati skausmo intensyvumo suvokimą. Nebuvo nustatyta skausmo intensyvumo ir pasidavimo skausmui ryšio, ir tai nesutampa su kitų autorių tyrimų rezultatais (Azevedo, Samulski, 2003).

Rasti ryšiai tarp skausmo suvokimo pagal semantinio diferencialo skales ir íveikos strategiju naudojimo dažnumo taip pat priklauso nuo skausmo tipo.

Kai raumenų skausmas suvokiamas kaip bjauresnis ir blogesnis, jam įveikti dažniau pasitelkiamos relaksacijos ir dèmesio atitraukimo strategijos. Šie rezultatai leidžia daryti prielaida, kad suvokdami raumenų skausmą kaip blogesni ar bjauresni (t. y. grèsmingesni), sportininkai imasi aktyvesniu ivveikos strategijų - mažina kūno ittampą, užsiima pašaline veikla, kad kuo mažiau jaustų skausmą ir leistų kūnui pailsèti. Kalbant apie dèmesio atitraukimo strategiją buvo užsiminta, kad skausmo ignoravimas gali mažinti skausmo kontrolès pojūtị ir dèl to skausmas suvokiamas neigiamiau (Haythornwaite et al., 1998). Rezultatai taip pat rodo, kad kuo labiau apklaustieji sportininkai raumenų skausmą vertina kaip bjauru, tuo dažniau jie yra linkę užsibrěžti sau tikslus, padedančius tą skausmą iveikti, ir kuo labiau ši skausmą suvokia kaip varginanti, tuo rečiau galvoja apie tai, kad yra buvę ir blogesnių situacijų.

Gyjančios traumos įveikai naudojamos teigiamų saviinstrukcijuc, pasidavimo ir demesio atitraukimo strategijos susijusios su šio skausmo suvokimu kontinuume žalingas / naudingas. Sportininkai linkę nuleisti rankas arba užsiimti veikla, nesusijusia su sportu, kai patiriamą gyjančios traumos skausmą sieja su žala, tačiau kai gyjančios traumos skausmą su būdvardžiu žalingas sieja mažiau, jie dažniau naudoja teigiamų saviinstrukcijų strategiją. Šie rezultatai patvirtina R. S. Roth ir M. E. Geisser
(2002) rastą ryši tarp tikèjimo, kad skausmas yra žalos ženklas ir dažnesnio neadaptyviu skausmo ivveikos strategijų (pvz., dramatizavimo) rinkimosi. Taigi panašu, kad skausmas gali būti suvokiamas kaip grèsmè arba kaip žala (Anshel, 2001), ir šiuos ivvertinimus svarbu atskirti. Mat tuomet, kai suvokiama grèsmé, labiau naudojamos aktyvios skausmo iveikos strategijos, tačiau kai skausmas suvokiamas kaip žala (jau įvykęs faktas), atsiranda tam tikras pasyvumas skausmo atžvilgiu. Vèlgi neaišku, ar skausmo suvokimas kaip žalingo skatina užimti tokią sąlygiškai pasyvią poziciją (,žala jau padaryta, nieko pakeisti nebegalima“), ar íveikos strategijų naudojimas keičia skausmo interpretaciją. Galbūt sportininkas, kuris save padrąsina ir nepasiduoda mintims, kad nieko negali padaryti skausmo atžvilgiu, šitaip pakeičia skausmo suvokimą ir vertina ji kaip mažiau žalingą.

Rezultatai taip pat rodo, kad sportininkai linkę tuo dažniau užsiimti veikla, nesusijusia su sportu, kuo labiau patiriamą gyjančios traumos skausmą vertina kaip blogą ir sunkų. Jie tuo mažiau juda, kuo labiau vertina ši skausmą kaip stiprų, ir tuo dažniau užsibrèžia tikslus, padedančius skausmą iveikti, kuo labiau šis skausmas suvokiamas kaip varginantis.

Sportininkai, suvokdami įsisenèjusi skausmą kaip stipresni, norèdami ji ivveikti, dažniau mėgina atpalaiduoti kūno įtampa, taip pat mažiau juda, kai ši skausmą suvokia kaip blogą. Tiesa, lieka neaišku, ar sportininkai, suvokdami skausmą kaip gerą, leidžia sau daugiau judèti, ar vertina skausmą kaip ne taip blogą tuomet, kai šis judeti trukdo mažiau.

Taigi skausmo ịveikos strategijos iš tiesų susijusios su skausmo suvokimu. İveikos proceso modelis (Anshel, 2001) siūlo interpretuoti šiuos ryšius taip: skausmo suvokimas lemia iveikos strategijų pasirinkimą, tačiau tikriausiai šie ryšiai yra abipusiai. Bet kuriuo atveju jie turètu būti išsamiau ištirti.

\section{IŠVADOS}

1. Sportuojant dominuoja šie patiriamo skausmo suvokimo neigiami aspektai - jis suvokiamas kaip blogas, bjaurus, stiprus, sunkus, ūmus, itempiantis, silpnejantis ir varginantis.

2. Skausmo ịveikos strategijų pasirinkimas susijęs su skausmo intensyvumo suvokimu ir skausmo suvokimu pagal semantinio diferencialo skales, tačiau šie ryšiai priklauso nuo skausmo tipo bei iveikos strategiju. 


\title{
LITERATŪRA
}

Addison, T., Kremer, J., Bell, R. (1998). Understanding the psychology of pain in sport. The Irish Journal of Psychology, 19, 4, 486-503.

Anshel, M. H. (2001). Qualitative validation of a model for coping with acute stress in sports. Journal of Sport Behavior, Vol. 24, Issue 3, 223-246.

Azevedo, D. C., Samulski, D. M. (2003). Assessment of psychological pain management techniques: A comparative study between athletes and non-athletes. Review of Brazilian Medicine and Sport, Vol. 9, 4, 214-221. Prieiga per internetą: www.scielo.br/pdf/rbme/v9n4/a03v9n4.pdf

Haythornwaite, J. A., Menefee, L. A., Heinberg, L. J., Clark, M. R. (1998). Pain coping strategies predict perceived control over pain. Pain, 77 (1), 33-39.

Huskisson, E. C. (1974). Measurement of pain. The Lancet, 9 (2), 1127-1131.

Kleinert, J. (2002). Zur Erfassung des Schmerzbewältigungsstatus bei Verletzungen (SBS-V): Skalenkonstruktion und Befunde zur Validität und Reliabilität. Psychologische Prävention von Sportverletzungen: Beiträge zur Diagnostik, Modellbildung und Intervention. $\mathrm{Ku}$ mulative Habilitationsschrift zur Erlangung der Lehrbefähigung für das Fach Sportwissenschaft unter besonderer Berücksichtigung von Sportpsychologie und Gesundheitsforschung. Köln. P. 37-54.

Lefevbre, J. C., Lester, N., Keefe, F. J. (1995). Pain in young adults II: The use and perceived effectiveness of pain-coping strategies (abstract). Clinical Journal of Pain, 11 (1), 36-44.

McCracken, L. M., Goetsch, V. L., Semenchuk, E. M. (1998). Coping with pain produced by physical activity in persons with chronic low back pain: immediate assessment following a specific pain event. Behavioral Medicine, Vol. 24, Issue 1, 29-34.

Roessler, K. K. (2003). Pain and sports - passion, challenge or obstacle: XI European Congress of Sport Psychology, Copenhagen, 22-27, July.

Roth, R. S., Geisser, M. E. (2002). Educational achievement and chronic pain disability: mediating role of pain-related cognitions (abstract). Clinical Journal of Pain, 18 (5), 286-296.

Scott, V., Gijsbers, K. (1981). Pain perception in competitive swimmers. British Medical Journal, Vol. $283,91-93$.

Suslavičius, A. (1988). Semantinio diferencialo metodika. Vilnius: Vilniaus valstybinis V. Kapsuko universitetas.

\section{PAIN IN SPORT: THE CORRELATION BETWEEN PAIN PERCEPTION AND THE STRATEGIES OF COPING WITH PAIN}

\author{
Lina Vaisetaitè ${ }^{1}$, Rūta Sargautytè $\dot{2}^{2}$ \\ Vilnius Olympic Sport Center', Vilnius University², Vilnius, Lithuania
}

\begin{abstract}
The goal of this research was to clarify how athletes perceive pain and what are the correlations between pain perception and the frequency of the use of pain coping strategies. Three types of pain, namely muscle pain, healing injury pain and far-gone pain were taken into consideration.

50 athletes representing athletics, rowing, cycling and swimming participated in the research and filled in the questionnaires, comprised of Visual Analogue Scales (Huskisson, 1974), Semantic Differential Scale (Suslavičius, 1988) and PMS-I (Kleinert, 2002) questionnaire.

The results revealed that the mean evaluation of muscle pain intensity was 42.64 , the mean intensity of healing injury pain -60.51 and the mean intensity of far-gone pain -57.81 . The rating of muscle pain was significantly lower than the rating of healing injury and far-gone pain (in both cases $p<0.01$ ). According to Semantic Differential Scales, pain was perceived as bad, awful, intense, heavy, acute, tensing, decreasing and tiring, however muscle pain was perceived as useful while healing injury pain and far-gone pain were perceived as harmful. The results also confirmed relationships between pain perception and the frequency of the use of pain coping strategies, however specific associations depend on the type of pain and coping strategies that are taken into account.
\end{abstract}

Keywords: pain perception, pain coping strategies, muscle pain, injury pain, far-gone pain.

Gauta 2005 m. spalio $11 \mathrm{~d}$.

Received on October 11, 2005

Priimta 2005 m. gruodžio $28 \mathrm{~d}$.

Accepted on December 28, 2005
Lina Vaisetaitè

Vilniaus olimpinis sporto centras (Vilnius Olympic Sport Center)

Pamėnkalnio g. 17 / 3, LT-01119 Vilnius

Lietuva (Lithuania)

Tel +37061032788

E-maillinavais@takas.lt 